ORIGINAL ARTICLE / ARTIGO ORIGINAL

\title{
Social representations of obstetricians and neonatologists about fetal and early neonatal death certificate in the city of São Paulo
}

\author{
Representações sociais de médicos obstetras e neonatologistas sobre \\ declaração de óbito fetal e neonatal precoce no município de São Paulo
}

Daniela Schoeps', Fernando Lefevre"I, Zilda Pereira Silva', Hillegonda Maria Dutilh Novaes"', Priscila Ribeiro Raspantini', Márcia Furquim de Almeida'

\begin{abstract}
Introduction: The insatisfactory completeness of the variables in the Death Certificate (DC) makes it difficult to obtain specific perinatal mortality indicators. Objective: To assess the social representation of physicians about the perinatal DC. Methods: Twenty-five physicians were interviewed in 15 hospitals in the city of São Paulo, in 2009. Qualitative analysis was performed with the Collective Subject Discourse technique. Results: The DC is primarily considered according to its legal aspect. Physicians feel responsible for fulfilling the cause of death. The majority of them reported receiving help from other professionals to complete information on maternal characteristics and identification variables. There is lack of information on the mother's pre-natal conditions, which can make it difficult to identify the perinatal cause of death, mainly in the Unified Health System (SUS) hospitals. Some participants received specific DC training only when attending medical schools. Conclusions: The organization of medical work may affect the completion of the DC, especially in hospitals from SUS. Other professionals contributed to this task and their training can improve the quality of information.
\end{abstract}

Keywords: Information systems. Death certificates. Social representation. Medical records. Qualitative Analysis. Perinatal mortality.

'Departamento de Epidemiologia da Faculdade de Saúde Pública da Universidade de São Paulo - São Paulo (SP), Brasil. "Departamento de Prática de Saúde Pública da Faculdade de Saúde Pública da Universidade de São Paulo - São Paulo (SP), Brasil. "'Departamento de Medicina Preventiva da Faculdade de Medicina da Universidade de São Paulo - São Paulo (SP), Brasil. Corresponding author: Daniela Schoeps. Faculdade de Saúde Pública da Universidade de São Paulo. Avenida Dr. Arnaldo, 715, Cerqueira César, CEP: 01246-904, São Paulo, SP, Brasil. E-mail: schoeps@usp.br

Conflict of interests: nothing to declare - Financial support: São Paulo Research Foundation (FAPESP), National Council of Scientific and Technological Development (CNPq), Research Program for the Unified Health System (PPSUS), Process n.: 2006/61304-3. 
RESUMO: Introdução: A completitude insatisfatória de algumas variáveis da Declaração de Óbito (DO) dificulta a obtenção de indicadores específicos de mortalidade perinatal. Objetivo: Avaliar a representação social dos médicos sobre as DOs perinatais. Métodos: Foram entrevistados 25 médicos em 15 hospitais, no município de São Paulo, em 2009. Foi realizada análise qualitativa com a técnica do Discurso do Sujeito Coletivo (DSC). Resultados: Grande parte dos médicos vê a DO sob o seu aspecto legal e dá ênfase ao preenchimento da causa de morte em detrimento de outras variáveis. A maioria dos médicos relatou receber auxílio de outros profissionais para preenchimento das informações de identificação e características maternas. Nos hospitais do Sistema Único de Saúde (SUS), a ausência de informações sobre a evolução da gestação dificulta a definição da causa do óbito perinatal. Parte dos entrevistados recebeu treinamento apenas durante a graduação em medicina. Conclusões: A organização e a rotina do trabalho médico podem afetar o preenchimento da DO. Principalmente nos hospitais do SUS, foi observada colaboração de enfermeiros e profissionais do setor administrativo, cujo treinamento para preenchimento do documento poderia aprimorar a qualidade das informações.

Palavras-chave: Sistemas de informação. Declaração de óbito. Representação social. Registros médicos. Qualidade da informação. Mortalidade perinatal.

\section{INTRODUCTION}

The Mortality Information System (SIM) was created in 1975 and represented an innovative concept for the existing health information systems. It implemented a standardized individual data form, partly pre-codified for data collection and the introduction of a Death Certificate (DC) according to guidelines proposed by the World Health Organization ${ }^{1}$. Since the creation of SIM, the Ministry of Health in Brazil has improved information and technical routine guidelines to qualify and operate the system. With the creation of the Brazilian National Public Health Care System (SUS) in 1988, an increased participation of the municipal level in the management of health actions occurred, which led to the decentralization of the system in $1998^{2}$.

Progress of information technology incorporated to the system and the creation of a program for the automatic selection of the underlying Cause of Death simplified and standardized codification of cause of death, enabling transferring SIM management to the municipal level ${ }^{3}$, established by a resolution from 2004. The Health Surveillance Secretariat of the $\mathrm{MoH}$, national manager of SIM, defined rules and regulated data insertion and flow in local systems ${ }^{4}$, which led to more agility in the production and better data quality. 
According to manuals and procedures of the National and Regional Medical Councils $(\mathrm{CRM})^{5}$ and the Ministry of Health ${ }^{6}$, the physician responsible for patient care should register the identification of the patient based on a document of the deceased person, with legible handwriting and register the causes of death according to international guidelines. According to manuals, the physician is ethically and legally responsible for filling in and signing the DC, and for the validity of the information registered in the whole document, which should not be signed before all the fields have been revised. There is a legal purpose for the emission of the death certificate, and the use of such information for epidemiological studies is increasing.

A literature review of the quality of data and methods used in the evaluation of health information systems in Brazil, conducted by Lima et al. ${ }^{7}$, pointed out that $48 \%$ of the selected articles referred to SIM, and $90 \%$ assessed the quality of data, considering four dimensions: reliability, completeness, coverage and validity.

One of the critical elements for the success of an information system is quality control of procedures in the stages of data collection and processing ${ }^{8,9}$. Quality of information depends especially on adequate processes to collect data that where the event occurred. Health services are the main source of data from SIM, and their quality depends on the registration of patient hospital care information ${ }^{10}$. Institutional factors, such as the type of health service, as well as the structure and organization of services, can influence data registration and administrative support. Besides, the level of data informatization, the level of decentralization of information systems and the management of these systems can also be important ${ }^{11}$, as well as training and routine quality control of information in all of the production stages.

The collection of death-related data takes place mostly in hospitals, which in Brazil account for 6,400 institutions enrolled in the National Register of Health Establishments, an extensive network of units for data collection. However, even though vital events are concentrated in hospitals, only a few studies assess how information is produced in these contexts. According to Arts et al. ${ }^{8}$, in order to ensure the quality of information, it is necessary to make sure adequate processes are employed in the stage prior to data collection, for instance, protocols of registration and collection with clear definitions, as well as training and motivation of the professionals in charge of filling out the information.

The study of the information production process can contribute to improve the quality of the perinatal mortality indicator, which allows the assessment of prenatal, labor and newborn care. With increasing coverage and informatization, it is easier nowadays to access data bases, and in theory this would enable the development of specific indicators in Brazil, such as perinatal mortality according to the age of the mother, type of pregnancy, weight at birth and during pregnancy. These indicators are essential as monitoring tools, and important elements to assess the quality of labor and newborn care ${ }^{12}$. However, one of the difficulties has been the unsatisfactory completeness of some of the variables, which prevents the calculation of these indicators ${ }^{13}$. 
Physicians are responsible for filling out the DCs, and institutional differences, structure, organization and type of health services can interfere in the daily routine of the professional, and, consequently, in data registration in the DCs. In this study medical doctors were interviewed in order to assess their social representations about existing information on fetal and neonatal death in a sample of hospitals from SUS or not SUS, in the city of São Paulo. A qualitative approach was used, in order to understand how data registration occurs in perinatal DCs, from the perspective of those responsible for it, in different institutions that produce patient care information, leading to a socially contextualized representation ${ }^{14}$.

\section{METHODS}

\section{HOSPITALS IN THE STUDY}

The study was conducted as part of a larger research project ("Avaliação da Qualidade da Informação sobre Mortalidade Perinatal no Município de São Paulo"), with a sample of hospitals selected from hospitals stratified in SUS and Non-SUS, and according to the number of perinatal deaths in each institution. The sample of hospitals was composed by 8 non-SUS and 14 SUS, including hospitals managed by philanthropic, public (regional and municipal) and other health management institutions. Two hospitals from SUS were excluded from the study, and three hospitals refused to participate (one SUS and two non-SUS).

\section{CHARACTERISTICS OF THE STUDY POPULATION AND INTERVIEWS}

Among the 17 participant hospitals, two did not indicate professionals to be interviewed; therefore, doctors were interviewed in 15 hospitals in 2009. Semi-structured interviews with open questions were composed by a predefined script and aimed at identifying the social representations of the physicians concerning the Mortality Information System (SIM) and filling in these documents in their routine activities. A pre-test was conducted to calibrate the interview in hospitals not participating in the study.

The defined criterion was to interview physicians directly involved in the routine of filling out fetal and neonatal DCs. In a hospital that was not from SUS, a doctor indicated by the coordination reported never having filled out the document, and because of that, the interview was not conducted.

In total, 25 doctors were interviewed, being 6 from non-SUS and 19 from SUS hospitals. Obstetricians usually fill out the fetal DCs. On the other hand, neonatal deaths DCs can be filled out by neonatologists, pediatricians or even obstetricians, 
when the event occurs in the labor room in the absence of the pediatrician. Therefore, 13 obstetricians, 11 neonatologists and 1 pathologist of hospitals with services of post mortem examination were interviewed.

The interview included questions that aimed at identifying aspects concerning training/ capacitation to fill out the documents, behavior of professionals when having doubts or difficulties about filling out the documents, as well as their opinions about the purposes/ uses of DCs. Interviews were carried out in the hospitals, being recorded and transcribed for the analysis of information.

\section{DATA ANALYSIS}

The research was analyzed by the Discourse of the Collective Subject (DCS) method and the software Qualiquantisoft ${ }^{15}$, which enables qualitative and quantitative methodological procedures and recovers the discursive and argumentative nature of thought in a collective perspective. The opinion is obtained by open questions, which leads the interviewee to create a discursive testimony. Each question generates a number of different opinions, that is, of different DCSs, a result from the aggregation of different discourses or extracts from individual discourses that represent similar meaning ${ }^{16,17}$.

The discourse of each interviewee can contain one or more ideas concerning a question. For the analysis process, key-expressions are attributed to each idea, so that it is possible to gather similar expressions and create categories of answers. With these categories and their respective discourses, it is possible to analyze similar ideas in each of the questions. The sum of the results corresponds to the number of ideas in each category, and not to the number of interviewed subjects ${ }^{16,17}$.

By the qualitative approach, interviewees express their ideas and talk about a theme by expressing meanings, motives, aspirations, beliefs, values and attitudes, which reflect a space of relationships, processes and phenomena. The idea is to understand the phenomena in terms of meanings given by the interviewees; however, since objective reality cannot be captured, the objective is to know these meanings by representations. The interviewed subject is not only a product of social determinations nor an individual product, since representations are always contextualized constructions ${ }^{18}$. The research was previously approved by the Research Ethics Committee of the School of Public Health at Universidade de São Paulo (USP), the hospitals and the Municipal Secretariat of Health, from the city hall of São Paulo. Before the interviews, the informed consent form was read and signed, therefore ensuring the anonymity of doctors who participated and the hospitals in which the research was conducted. 


\section{RESULTS}

Interviews were conducted with 13 gynecologists/obstetricians, 11 neonatologists and 1 pathologist, responsible for the post mortem examinations of a death verification sector at a school hospital. Most of the interviewed doctors (20) worked also in another hospital, five of them worked only in the hospital where the interview was conducted.

Concerning the routine work, 14 doctors worked exclusively by assisting patients, and 10 of them reported also having managerial positions or research activities. The routine of these professionals involved not only health care, but also assistance to interns and participation in committees, the latter reported only by doctors in SUS hospitals.

They were asked if filling out death certificates was part of their work routine (Chart 1). Eight doctors from SUS and one from a non-SUS hospital said they did not fill out the DC at the time of the study, since perinatal deaths were sent to the Municipal Coroners Service (SVO); however, these doctors mentioned they had filled out the document in other situations.

Doctors who filled out documents in the period in which interviews were conducted reported two situations: the first one, in a non-SUS hospital, the doctor claimed there was no assistance to fill out the DC, and that each doctor fills out the documents concerning his own patients, since there is no team in the hospital for this activity. However, situations in which the doctors receive help from other professionals in the hospital to fill out the documents have been reported; for instance, they describe that the death certificate (DC) arrives partly filled in with what is called bureaucratic information, that is, identification data, characteristics of the mother, pregnancy and the newborn, so they only fill in the medical-related part, which, for these professionals, are the causes of death. Therefore, epidemiological data such as age, mother parity, prenatal appointments and duration of pregnancy are usually considered as bureaucratic information.

Chart 2 shows the central ideas related to the question: "Do you consider there is any difficulty to fill int some kind of information? Which one(s)?” With regard to category A, six doctors

Chart 1. Physicians' report about filling out the Death Certificate in the Unified Health System and non-Unified Health System hospitals, São Paulo, 2009.

\section{Work routine about filling out the perinatal Death Certificate}

\begin{tabular}{c|r} 
A & $\begin{array}{r}\text { Doctor mentions situations and forwards death to the Service of Death Verification } \\
\text { or post mortem examination }\end{array}$ \\
\hline B & $\begin{array}{r}\text { The doctor who followed-up the patient is not always the same one who fills out the Death Certificate } \\
\text { C }\end{array}$ \\
\hline D & The doctor is assisted by other professional in the hospitals to fill out the Death Certificate \\
\hline E & The doctor who assisted the patient fills out the document
\end{tabular}


reported having no difficulties. The question was divided (or expressed) in subcategories of answers: A.1 - no difficulties, because they have experience in filling out the document, so they do it naturally; A.2 - no difficulties when the cause of death is apparent; A.3 - in the hospital, there is a routine to register information that indicates the evolution of the patient, which makes it easier to determine the cause of death; A.4 - one doctor reported not having difficulties because he sends the body to the coroner office.

Among the interviewees who reported having difficulties, the need to look up in other sources of information (category D) is one of the most mentioned factors:

Look, you mean the death certificate as a whole, right? It is not only about what concerns the doctor, the items of the death certificate, the bureaucratic part, let's say, observations the doctor can make, like, one patient you did not follow-up, so we feel there are some difficulties with data related to the mother, the schooling of the mother, if the mother is married or not, so these little items sometimes are not informed by the obstetrician in the file, or the pediatrician who sees the child in the labor room. We have difficulties to fill in these data, especially concerning the schooling of the mother, age, if there was a prenatal treatment or not, and there is also the number of appointments to fill out. If the patient did not bring any prenatal care card, you have to guess. Sometimes the patient has it but didn't bring it, sometimes the patient really doesn't have it and claims to have forgotten it, so in a way it is a risky pregnancy. If a patient comes, for instance, at the $30^{\text {th }}$ pregnancy week, but she tells me she is 9 months pregnant, we imagine there could be a retarded growth fetus, but it could also be premature. We have to look carefully, to repeat the examinations in the emergency room, to make an ultrasound, so we can evaluate if there is a delay, which can be a little tricky. There are some specific fields in the death certificate, and sometimes the colleagues do not use a lot of words in the records, and so we have difficulties to elaborate the diagnosis.

This discourse indicates that the routine of registering information in documents plays an important role in order to make data more reliable, since registering/identifying the patient, sometimes in an urgent hospital admission, might also depend on formation provided by relatives or carers, when insufficient medical data has been registered in the records.

Chart 2. Difficulties reported by physicians about filling out the Death Certificate in the Unified Health System and non-Unified Health System hospitals, São Paulo, 2009.

\begin{tabular}{c|c} 
& Difficulties to fill out the Death Certificate \\
\hline A & No difficulties \\
\hline B & Difficulties to define the cause of death \\
\hline C & Difficulties to fill out "death evolution" \\
\hline D & Difficulties to search for other sources of information \\
\hline E & Difficulties concerning the Death Certificate "form" \\
\hline G & Filling out the Death Certificate is stressfull for the doctor
\end{tabular}


The difficulty to fill out "death evolution", referring to the block of "conditions and causes of death" in the DC (category C) involved doubts concerning the indication of the basic cause of death. In this case, the consequential causes, or the ones that contributed with death, should be registered. The difficulty to define the cause of death (category B) was reported especially by doctors of hospitals from SUS.

After approaching the difficulties, the following question was asked: "Were you trained/informed about how to fill out the DC? If so, what did you think of this training?" As pointed out in Chart 3, some interviewees reported having received training only during university or residency:

I'll tell you, we had this class at the university, but if you ask me at what period, I cannot remember it, but I recall that we had this class, perhaps in the fourth year. I don't recall it very well, but what I remember is that the teacher passed by every item speaking, emphasizing the importance of the cause of death when the death is related to a young woman, at reproductive age, something like that. I remember it is important to fill it in, and to fill in as much as we can. We also received that book, I think it was from the School of Public Health. Here in the hospital I have never seen this type of training. After that it is over, there is some information here and there, and with experience we learn how to deal with the situation. In fact, it is based on the cases that come up, there isn't even a specific class about how to fill out a death certificate. There is a class during university and we end up adapting it to the stillbirth, it happens. So there is some information we receive at the medical school and the rest is by experience with cases, during residency and in our professional lives. But I have never seen a specific class about how to fill out a death certificate for still birth.

The discourse concerning the training to fill out DCs at specific classes during the medical school shows a distant reality from the daily work in hospitals and the need for updates and constant lectures.

Some hospitals, mostly from SUS, offer speeches (categories A and B) related to filling out the DC and raising awareness about the DC being one of the patient's rights. According to the interviewees, these events are important and should happen more often. A doctor

Chart 3. Aspects of training reported by physicians to fill out the Death Certificate in the Unified Health System and non-Unified Health System hospitals, São Paulo, 2009.

\begin{tabular}{c|r} 
& Aspects of training to fill out the Death Certificate \\
\hline A & Hospital provides constant training and lectures \\
\hline B & Hospital provides sporadic training and lectures \\
\hline C & Received training only in college or during residency \\
\hline D & Learned how to fill out the Death Certificate with the Filling Out Manual or leaflets \\
\hline E & Received training from the city hall or the regional medical council \\
\hline F & Never received training
\end{tabular}


from a hospital that was not from SUS reported having participated in a class in another hospital during a mandatory clinical meeting, since it was a reference school hospital. As the interviewee reports, it is very difficult to provide this kind of lecture, because doctors are not interested in it:

Ok, if I schedule a meeting to talk about this information, nobody will come. Only if I make physicians on duty come, or else they would be fired, because only inviting them will not do it, nobody will come. This is not famous among doctors, nobody comes, so, if I ask the Regional Medical Council to come and offer a major meeting, with dinner, nobody would come. The doctor is not interested in it at all.

Other professionals reported having learned to fill out the DCs in their daily routine (with no specific training) and, to learn more or clarify doubts, they use the Manual and leaflets sent by the Regional Medical Council or the Program of Mortality Information Improvement in the city of São Paulo (PROAIM), from the Municipal Secretariat of Health (category D). It is important to point out that the manual is not always available; one of the doctors found it by accident with other documents, and then began to use it. Two doctors from SUS hospitals claimed not having been trained, and they learned how to fill out the form with the assistance of other colleagues and nurses (category F).

Interviewees reported having watched lectures or participated in trainings provided by the regional medical council or by PROAIM (category E), and found the experience was important for self-improvement and knowledge about the documents:

Trainings are important because they provide doctors with knowledge, help improve the filling in process, and I think improving the Coroners Office work and the Live Birth Declaration are essential so we can have reliable statistics in this country... if it is like that in São Paulo, I can only imagine how it is out there. There is also the fact that, now maybe a little less, but sometimes when there is a report or a death declaration that is not right, the PROAIM sends a letter addressed to us after some months mentioning it should have been filled in like this, and not like that.

In order to continue the training, the following question was asked: "Do you have any help to fill out the DCs? If so, for which type of information?". Such a question aimed at identifying how the doctor acts when he or she has any doubts or difficulties to fill out the documents, or if they fill out the DC alone.

As demonstrated by Chart 4, the most frequent central idea (category A) was that the doctor usually talks to other doctors, especially concerning the cause of death:

Sometimes, if we have any doubts about a diagnosis, we confirm it with our colleagues, so, we can confirm the death as being: 'prematurity, led to multiple organ immaturity'. Concerning the causes of death, we are among colleagues, and we talk about it, we know the patient, who was there, and 
we want to define better what was the main cause, the secondary cause. This way we can all agree, because we also have to consider that anything we say nowadays can be used against us, and especially concerning suits, I think it is more of a moral support than anything else. But not a higher entity in the hospital or board. So, it is usually what I told you, most forms are already filled out, we only fill out the medical part.

This text indicates that the doctor feels he is only in charge of the DC field concerning the cause of death. The central ideas B and C indicate that the other fields are filled out by other professionals in the hospital, who have this responsibility internally:

I feel no difficulties because the reception, or the staff that identifies and admits the patient, usually fills int the place of death, the address, and these data are filled in by them. We do the medical part, and the rest is done by the staff in the bureaucracy (administration).

Doubts concerning the cause of death and fields are related to patient identification, data filled out by the administrative department of the hospital, such as gestational age, parity and number of live and dead children. These variables do not stand out in the filling in routine; however, when doctors are asked about the use of information in the DC (Chart 5), most of them were aware of the importance of these data for epidemiological use and for public health. Besides the epidemiological importance, reports have been given about the use of information for the hospital, for legal purposes and for the family.

Chart 4. Positioning in the face of doubts to fill out the Death Certificate reported by physicians in the Unified Health System and non-Unified Health System hospitals, São Paulo, 2009.

Positioning of doctors facing possible doubts to fill out the perinatal Death Certificate

\begin{tabular}{c|r} 
A & Talk about doubts and discusses causes of death with other doctors \\
\hline B & Look for information with the nurses \\
\hline C & Have no doubts because the administrative sector fills out part of the Death Certificate \\
\hline D & Try to fill out the document as correctly as possible
\end{tabular}

Chart 5. Use of SIM information pointed out by physicians in the Unified Health System and non-Unified Health System hospitals, São Paulo, 2009.

\begin{tabular}{c|c} 
& Category \\
\hline A & Information has epidemiological and public health purposes \\
\hline B & These data are important for the hospital \\
\hline C & These data have legal ends \\
\hline D & These data are important for the family
\end{tabular}




\section{DISCUSSION}

The different functions, occupations and work regime of the interviewed doctors, in different contexts and work situations, may lead to differences in the social representations they have about the DC.

When doctors work in more than one hospital, it may influence the routine of filling out the DCs, since these professionals can bring experiences from other establishments to the their practice. Coordination or clinical board activities involve not only medical care, but also participation in mortality and research committees, where part of the data from the DCs can be used. Therefore, this is a different social representation of this document. The main attribution of the physician on duty in his or her work routine is to provide medical care, but the filling out of the documents related to the patient is part of that routine, even though it is not its main aspect.

In the current model of health care, especially concerning attention to the pregnant woman during labor, there is a fragmentation of the medical work in the hospitals from SUS, which can be expressed in two ways. The first one refers to professionals on duty, where the production of medical services is stratified in terms of institutional teams, that is, instead of specific professionals on a daily basis there are teams that work in shifts, but that do not necessarily relate to the same case (patient) ${ }^{19}$.

The second form of fragmentation occurs when obstetricians perform labors of patients they did not follow-up during pregnancy, which leads to the difficulty reported by the interviewee to determine the cause of prenatal fetal death or the indication of the basic cause of death in perinatal deaths.

In this situation, prenatal fetal deaths are considered to have indeterminate cause, and are usually sent to the Coroners Office ${ }^{20}$. This situation also reflects a specificity of the routine in the city of São Paulo, given the existence and the proximity of the Coroners Office, and this fact results in the high number of fetal DCs filled out by the Office (75\%). However, the premise that forwarding the case to the Office improves diagnosis of the cause of deaths is not always true, because a study showed that autopsy did not result in improvement of the indication of causes of fetal death ${ }^{20}$.

Besides the real difficulties to diagnose the cause of death in intrauterine death, health professionals can also be reluctant to report unfavorable outcomes ${ }^{21,22}$. In hospitals that are not from SUS, this difficulty was not mentioned, because usually the doctor who conducted labor was the same one who followed-up the mother during pregnancy. These differences reinforce the hypothesis that institutional differences and the organization of health services interfere in the routine of the doctor, therefore, interfere in the action of filing out the documents.

Considering the differences between the organization of medical work in hospitals from SUS or not, among the difficulties related to filling out the documents described by the doctors in hospitals from SUS is information regarding the mother, since the information that is present in the prenatal card is not always available at the time of labor, which makes 
it difficult to define the cause of death. This also reflects on the quality of information registered in hospital records. Such a difficulty could be minimized by integrating prenatal and labor care, by means of informatizing, making available, and sharing the mother's medical history and records with the doctor that cares for the pregnant woman and the newborn.

It is worth to mention that the quality of hospital records and other sources of data registration also impact the availability of information ${ }^{8,9}$. A study conducted by Mendonça et $\mathrm{al}^{22}$ observed that there are difficulties to fill out the DC due to the lack of data registers in medical records.

Another mentioned difficulty is the need to use different sources (medical record or asking the mother), which indicates that information, according to the interviewees, is organized in a fragmented way, which contribute with the perception of information that is segmented into bureaucratic (data concerning the identification of patients, as well as characteristics of the mother and the pregnancy) and clinical (process of the condition that led to death). This fragmentation can also contribute with the difficulty to value of several epidemiological variables (age and mother parity, weight at birth), which are on the causal path to perinatal deaths.

When doctors were asked about feeling difficulties to fill out the DC, it was clear that they feel responsible only for the field related to the cause of death, while the other data are usually addressed to other administrative sectors of the hospital (SAME, patient's admission). This result confirms the findings by Mendonça et al. ${ }^{22}$ and Niobey et al. ${ }^{23}$.

According to resolution of the Ministry of Health 20/03, of the Health Surveillance Secretariat, article 8 , the death declaration should be used all over the country, for the collection of data concerning deaths, being "indispensable for the notification, by the Civil Register office, the Death Certificate", that is, while it is the base document for SIM, it is also essential for producing the death certificate, a civil legal document. Considering this double purpose, the interviews make it clear that the physician is dedicated to certifying death and for the legal purposes of the DC, as has been discussed by Lopes ${ }^{24}$. Even though the attitude of the physicians especially contemplates legal aspects, several professionals mentioned the importance of data for epidemiological studies. The emphasis on the legal aspect of the DC and on the action of filling in the cause of death, as part of routine work, has consequences for the quality of the filled out declarations, because only the doctors are trained to do it and, yet, many of them were only advised during residency or in classes during medical school. The other professionals who, in practice, fill out specific fields of the DCs end up not receiving specific training, which can interfere in the quality of information. According to Arts et al.8, the main filling in mistakes include the unclear definition of variables and the violation of the protocol. Quality could be improved with specific training for professionals who, in fact, are in charge of filling out the DC. In the United States, there is a specific declaration for fetal death and one person in charge of filling out the document, the "funeral director", who must collect information in predefined sources; the cause of death should be obtained from the doctor who was on 
duty, while personal data should be collected from family members (there is a preferable kinship order $)^{25}$.

Interviews with physicians enabled the identification of their social representations about filling out the DCs and how this activity is part of their daily routine. However, this qualitative study aimed at exploring the perception of doctors, and may not have demonstrated the complexity of all of the aspects involving the production of mortalityrelated information.

\section{CONCLUSION}

The dynamics of the current hospital service model, in which, especially inside SUS, the doctor who performed labor or the pediatrician has no access to information concerning the evolution of pregnancy, makes it difficult to establish the cause of death. Even though interviewees recognized the importance of the information in the DCs in epidemiological studies, they point out to the legal importance of the document, they do not see themselves as contributors to the system that generates these data, and this perception influences the quality of data registration.

\section{REFERENCES}

1. Baldijão MFA. Sistemas de informação em saúde. São Paulo em Perspectiva 1992; 6(4): 21-8.

2. Brasil. Ministério da Saúde. Secretaria de Vigilância em Saúde. Portaria n ${ }^{\circ} 3.947$ / GM, de 25 de novembro de 1998. Estabelece os padrões comuns dos sistemas e bases de dados na área da saúde. Publicada no Diário Oficial da União. 14 de janeiro de 1999, Seção 1:8.

3. Brasil. Ministério da Saúde. Secretaria de Vigilância em Saúde. Portaria MS/SVS n ${ }^{\circ} 20$, de 3 de outubro de 2003. Regulamenta a coleta de dados, fluxo e periodicidade de envio das informações sobre óbitos e nascidos vivos para os Sistemas de Informações em Saúde - SIM e Sinasc. Publicada no Diário Oficial da União. 9 de outubro de 2003, Seção 1:71.

4. Brasil. Ministério da Saúde. Secretaria de Vigilância em Saúde. Portaria n ${ }^{\circ}$ 116, de 11 de fevereiro de 2009. Regulamenta a coleta de dados, fluxo e periodicidade de envio das informações sobre óbitos e nascidos vivos para os Sistemas de Informações em Saúde SIM e Sinasc. Publicada no Diário Oficial da União. 12 de fevereiro de 2009, Seção 1:71.
5. Brasil. Ministério da Saúde. Declaração de óbito: documento necessário e importante. Conselho Federal de Medicina. Brasília; 2006.

6. Brasil. Ministério da Saúde. Secretaria de Vigilância em Saúde. Departamento de Análise de Situação de Saúde. Manual de Instruções para o preenchimento da Declaração de Óbito. Brasília; 2009.

7. Lima CRA, Schhramm JMA, Coeli CM, Silva MEM. Revisão das dimensões de qualidade dos dados e métodos aplicados na avaliação dos sistemas de informação em saúde. Cad Saúde Pública 2009; 25(10): 2095-109.

8. Arts DG, De Keizer NF, Scheffer GJ. Defining and improving data quality in medical registries: a literature review, case study, and generic framework. J Am Med Inform Assoc 2002; 9(6): 600-11.

9. Solomon DJ, Henry RC, Hogan JG, Van Amburg GH, Taylor J. Evaluation and implementation of public health registries. Public Health Rep1991; 106(2): 141-50.

10. Terris DD, Litaker DG, Koroukian SM. Health state information derived from secondary databases is affected by multiple sources of bias. J Clin Epidemiol 2007; 60(7): $734-41$. 
11. Novaes, MHD. Da produção à avaliação de tecnologias dos sistemas de saúde: desafios do século XXI. Rev Saúde Pública 2006; 40: 133-40.

12. Zeitlin J, Wildman K, Bréart G, Alexander S, Barros H, Blondel B, et al. Selecting an indicator set for monitoring and evaluating perinatal health in Europe: criteria, methods and results from the PERISTAT project. Eur J Obstet Gynecol Reprod Biol 2003; 111(Suppl 1): S5-S14.

13. Almeida MF; Alencar GP; França Junior I, Novaes HMD, Siqueira AAF, Schoeps D, er al. Validade das informações das declarações de nascidos vivos com base em estudo de caso-controle. Cad Saúde Pública 2006; 22(3): 643-52.

14. Souza DV, Zioni F. Novas perspectivas de análise em investigações sobre meio ambiente: a teoria das Representações Sociais e a técnica qualitativa da triangulação de dados. Saude soc 2003; 12(2): 76-85.

15. SPi-Sales \& Paschoal informática. www.spi.com.br. Elaborado com base na teoria do DSC. (Acessado em 23 de janeiro de 2012)

16. Lefevre, F, Lefevre AMC. O discurso do sujeito coletivo: um novo enfoque em pesquisa (desdobramentos). Caxias do Sul: EDUCS; 2003.

17. Lefevre F, Lefevre AMC. O sujeito coletivo que fala. São Paulo: Interface; 2006. p. 517-20.

18. Spink MJP. O conceito de representação social na abordagem psicossocial. Cad Saúde Pública 1993; 9(3): 300-8.
19. Schraiber LB. O Trabalho Médico: Questões acerca da autonomia profissional. Cad Saúde Pública 1995; 11(1): 57-64.

20. Almeida MF, Alencar GP, Schoeps D, Minuci EG, Silva ZP, Ortiz LP, et al. Qualidade das informações registradas nas declarações de óbito fetal em São Paulo, SP. Rev Saúde Pública 2011; 45(5): 845-53.

21. Froen JF, Gordijn SJ, Abdel-Aleem H, Bergsjo P, Betran A, Duke CW, et al. Making stillbirths count, making numbers talk: issues in data collection for stillbirths. BMC Pregnancy Childbirth 2009; 9: 58.

22. Mendonça FM, Eliane D, Cardoso AMP. Problemas de preenchimento das Declarações de Óbito: estudo exploratório. R Bras Est Pop 2010; 27(2): 285-95.

23. Niobey FML, Cascão AM, Duchiade MP, Sabroza PC. Qualidade do preenchimento de atestados de óbitos de menores de um ano na região metropolitana do Rio de Janeiro. Rev Saúde Pública 1990;24(4): 311-8.

24. Lopes JCN. Aspectos éticos e jurídicos da declaração de óbito. Rev Bioét 2011; 19(2): 367-82.

25. National Center for Health Statistic. Specifications for Collecting and Editing the United States standard Certificates of Birth and Death - revision general guidelines. 2003.

Received on: 06/22/2012

Final version presented on: 12/10/2012

Accepted on: 12/12/2012 